Louisiana State University

LSU Digital Commons

$1-1-2013$

\title{
Synthesis and biological investigations of a ZnPc-antiCEA bioconjugate for imaging of colorectal cancer
}

\author{
Inder Sehgal \\ School of Veterinary Medicine \\ Hairong Li \\ Louisiana State University \\ Benson Ongarora \\ Louisiana State University \\ Daniel Devillier \\ Louisiana State University \\ M. Graça H. Vicente \\ Louisiana State University
}

Follow this and additional works at: https://digitalcommons.Isu.edu/chemistry_pubs

\section{Recommended Citation}

Sehgal, I., Li, H., Ongarora, B., Devillier, D., \& Vicente, M. (2013). Synthesis and biological investigations of a ZnPc-antiCEA bioconjugate for imaging of colorectal cancer. Journal of Porphyrins and Phthalocyanines, 17 (1-2), 150-156. https://doi.org/10.1142/S108842461250143X

This Article is brought to you for free and open access by the Department of Chemistry at LSU Digital Commons. It has been accepted for inclusion in Faculty Publications by an authorized administrator of LSU Digital Commons.

For more information, please contact ir@lsu.edu. 


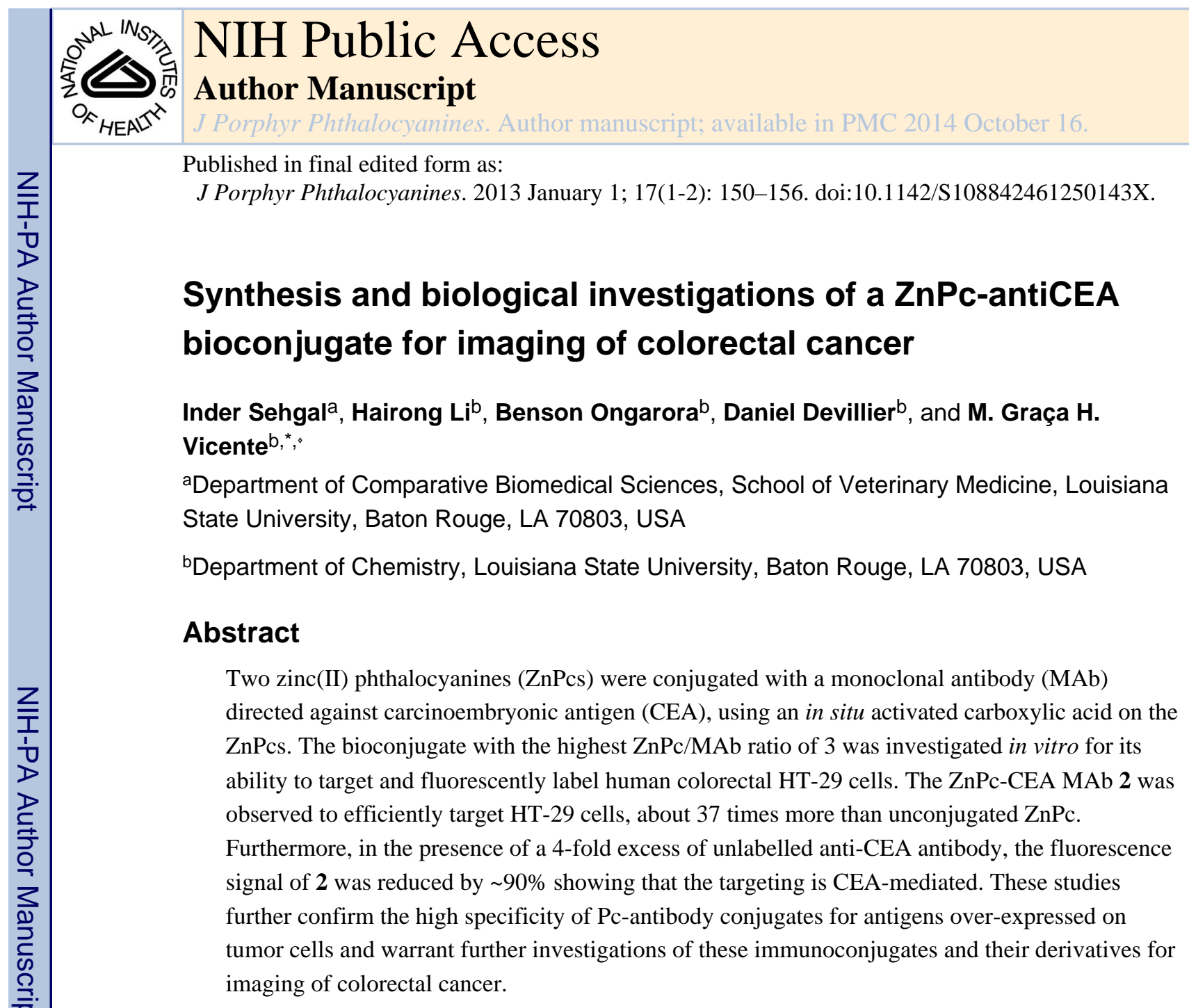

\section{Keywords}

phthalocyanine; carcinoembryonic antigen; antibody; colorectal cancer; fluorescence

\section{INTRODUCTION}

Colorectal cancer (CRC) is the third most common solid internal malignancy, with 243,460 new cases diagnosed in the US in 2012 [1]. Colon cancer typically progresses over a relatively long period and in a linear fashion from adenomatous polyps to carcinoma, and this time-interval allows for routine colon screening [1, 2]. Screening, detection and removal of polyp adenomas or early stage cancer can reduce the incidence of colorectal cancer by $80 \%$ [3] and it has been the advent of broader population screening that has largely led to the improvement in mortality observed during the past 20 years [1]. Current screening techniques include flexible sigmoidoscopy, standard colonoscopy, radiography and CT colonoscopy [4] with standard colonoscopy being the accepted gold standard screening method [2]. While these current technologies identify large adenomatous lesions, they

Copyright (๐ 2013 World Scientific Publishing Company

*Correspondence to: M. Graça H. Vicente, vicente@1su.edu, tel: +1 225-578-7405.

${ }^{\diamond} \mathrm{SPP}$ full member in good standing 
frequently miss at least two forms of early CRC: small adenomas $(<5 \mathrm{~mm})$ and flat lesions, particularly those in patients with ulcerative colitis [3]. The consequences of "hits" and "misses" following colonoscopic screening have been difficult to determine; however, in a recent population-based, case-controlled study, colonoscopy was found to reduce deaths from left-sided CRC but not deaths from right-sided cancers [5]. This study, the largest attempt to date to evaluate the relationship between colonoscopy and CRC-deaths, speculates that right-side CRCs are often small-sized or flat-shaped or more rapidly progressive. Therefore, successful preventive colonoscopic screening for CRC requires a more effective detection of early dysplastic lesions and cancer.

Improvements in colonoscopic techniques will likely be made by enhancing the sensitivity of cancer foci identification. Newer technologies that are being employed to accomplish this goal include chromoendoscopy, narrow band imaging, and blue light auto-fluorescence (reviewed in Ref. 4). In addition to these new surveillance techniques, once a region of interest is identified, a confocal laser microscope can be used for in situ histology. A confocal laser endomicroscope consists of confocal microscopic lenses integrated into the tip of an endoscope which projects laser light onto the mucosal surface. The fluorescent imaging agents used at the present time include fluorescein, acriflavine and cresyl violet. These agents stain mucosal tissue but they are non-specific and stain normal as well as neoplastic regions [3]. With improved specificity detection agents, confocal laser endomicroscopy could provide a powerful complement to standard endoscopy enabling subcellular resolution of colonic mucosa [3] and identifying intraepithelial neoplasias during colonoscopic exam. Fluorescence is a sensitive in vivo imaging technology that, if CRCselective, would be a more superior indicator of suspicious regions than relying on visualizing mucosal morphology alone. It would also reduce the need for random biopsies that are taken from at-risk patients during colonoscopy. Currently, one of the main barriers to the development of highly sensitive and effective near-IR fluorescence imaging is the lack of highly tumor-selective fluorophores. Advantages of near-IR fluorescence for bioimaging applications include low Raman scattering cross-sections associated with the use of low energy excitation photons, larger Raman-free observation windows and reduced absorption and fluorescence from other compounds [6]. Phthalocyanines (Pcs), also known as azaporphyrins, are a class of synthetic tetrapyrrolic compounds related to the naturally occurring porphyrins, containing an extended $18 \pi$-electron system. Due to their strong absorptions and emissions in the near-IR, Pcs have found multiple applications in biology and medicine as imaging agents and as photosensitizers for the photodynamic therapy (PDT) of cancers [7-9]. PDT involves light activation of a photosensitizer with subsequent in situ production of singlet oxygen and other reactive oxygen species (ROS), which destroy photosensitizer-accumulated cells via necrosis and/ or apoptosis [10, 11]. Photofrin is an FDA-approved porphyrin, a derivative of hematoporphyrin IX, that has been used for nearly two decades in the PDT treatment of various cancers, including lung, skin, cervical and bladder. Pcs have emerged as promising second-generation photosensitizers due to their intense absorptions at longer wavelengths $\left(\lambda_{\max }>670 \mathrm{~nm}\right)$ than porphyrins, and low dark toxicity. We have recently reported the conjugation of phthalocyanines to peptide ligands directed at the human epidermal growth factor receptor (EGFR), over-expressed in several cancer cell lines, including CRC [12]. These studies showed that certain ZnPc-peptide 
conjugates had low dark and phototoxicities, and efficiently accumulated in cancer cells over-expressing EGFR, up to 17 times more than unconjugated $\mathrm{ZnPc}, 24 \mathrm{~h}$ after exposure to A431 cells. Another methodology for selective delivery of fluorophores to tumor cells involves conjugation to antibodies tumor-associated antigens [13]. Herein we report the synthesis and conjugation of $\mathrm{ZnPcs}$ to monoclonal antibody (MAb) directed against carcinoembryonic antigen(CEA). CEA is most commonly associated with clinical CRC because of its widespread use as the serum marker used to evaluate CRC recurrence after treatment $[14,15]$. The CEA protein is a cell surface glycoprotein over-expressed in approximately $90 \%$ of all CRC and over $90 \%$ of precursor aberrant crypt foci. Expression of CEA is correlated with significantly higher ultimate patient mortality and metastatic potential $[16,17]$. Furthermore, CEA is non-internalizing, which is expected to minimize phototoxicity and favor the CRC-imaging application of the bioconjugate [18]. Here, we demonstrate the synthesis and cancer targeting selectivity of a ZnPc-anti-CEA conjugate as a lead imaging agent for fluorescent surveillance of colon cancer foci.

\section{RESULTS AND DISCUSSION}

\section{Synthesis}

The synthetic route to ZnPc-antiCEA bioconjugates $\mathbf{2}$ and $\mathbf{3}$ is shown in Scheme 1. The starting $\mathrm{ZnPc} 1$ was prepared as we have recently reported, from reaction of the corresponding aminophenoxy-substituted $\mathrm{ZnPc}$ [19] with diglycolic anhydride in DMF [12]. Activation of the carboxylic acid of ZnPc 1 using DIEA, HOBt and TBTU in DMSO, followed by addition of the commercially available anti-CEA MAb in $\mathrm{NaHCO}_{3}$ solution gave bioconjugate 2 . On the other hand, conjugation of $\mathrm{ZnPc} \mathbf{1}$ with commercially available tert-butyl protected PEG, followed by deprotection using TFA in dichloromethane, produced the corresponding ZnPc-PEG in $68 \%$ overall yield, as we have previously reported [12]. The conjugation of the Zn-PEG with anti-CEA MAb following a similar procedure, produced bioconjugate 3 . This coupling reaction between a Pc bearing an activated carboxylic acid and the MAb, randomly labels amino groups on the CEA, such as lysine residues. The $\mathrm{ZnPc} / \mathrm{CEA}$ molar ratio obtained from the coupling reactions was determined as previously reported [20-22], by measuring the absorbance at $280 \mathrm{~nm}$ to estimate the concentration of MAb and the absorbance at $338 \mathrm{~nm}$ to estimate the concentration of $\mathrm{ZnPc}$. The molar $\mathrm{MAb}$ and $\mathrm{ZnPc}$ concentrations were calculated using the formula $\mathrm{C}_{\mathrm{CEA}}=$ $\left[\mathrm{A}_{280 \mathrm{~nm}}-\left(0.5 \times \mathrm{A}_{\mathrm{ZnPc}}\right)\right] / \varepsilon_{\mathrm{CEA}}, \mathrm{C}_{\mathrm{ZnPc}}=\mathrm{A}_{\mathrm{ZnPc}} / \varepsilon_{\mathrm{ZnPc}}$ where $\varepsilon_{\mathrm{CEA}}=223,045\left(\mathrm{M}^{-1} . \mathrm{cm}^{-1}\right), \varepsilon_{\mathrm{Pc} 2}$ $=49,471\left(\mathrm{M}^{-1} \cdot \mathrm{cm}^{-1}\right)$ and $\varepsilon_{\mathrm{Pc} 3}=39,716\left(\mathrm{M}^{-1} \cdot \mathrm{cm}^{-1}\right)$. The extinction coefficients of the ZnPcs were determined by dissolving unconjugated $\mathrm{ZnPcs}$ in $0.1 \mathrm{M} \mathrm{NaHCO}_{3}$ containing $0.1 \%$ DMSO. For the case of ZcPc-antiCEA 2, a molar ratio of 3 was determined, while for bioconjugate $\mathbf{3}$, a ratio of 2 was obtained. The relatively low ratios determined might be as a result of the poor solubility of the $\mathrm{ZnPcs}$ in the basic aqueous media [23-25]. Molar ratios of 2 to 5 are usually considered optimal [26]. Based on our ratio result, bioconjugate 2 , bearing the highest $\mathrm{ZnPc} / \mathrm{CEA}$ ratio, was prepared in larger amount for preliminary biological evaluation (vide infra). 


\section{Studies in HT-29 cells}

The HT-29 cells were first immunostained with anti-CEA MAb to demonstrate the cell surface expression of the antigen in vitro, as shown in Fig. 1a. We then separately incubated the cells with $\mathrm{ZnPc}-\mathrm{CEA} \mathrm{MAb} 2$ at a concentration of $1 \mu \mathrm{M}$ for an $8 \mathrm{~h}$ period at $37{ }^{\circ} \mathrm{C}$, to allow for antibody binding. The fluorescence emission from the $\mathrm{ZnPc}$-CEA bioconjugate was imaged at $700 \mathrm{~nm}$. This emission pattern showed conjugate associated with HT-29 cells both on the cell surface as well as intracellularly, as shown in Fig. 1b. Since CEA is noninternalizable, the intracellular accumulation of Pc suggests MAb-mediated delivery of ZnPc to the cell surface and some degree of uncoupling of Pc from antibody, possibly the noncovalently coupled ZnPc, allowing free Pc to diffuse into the cell. However, when cells were incubated with the untargeted $\mathrm{ZnPc} 1$ alone at $10 \mu \mathrm{M}$, a 10-fold increase over the $\mathrm{ZnPc}$ levels used Fig. 1b, only a very low degree of fluorescence was detected, as shown in Fig. 1c. At $1 \mu \mathrm{M}$, an amount equivalent to the $\mathrm{ZnPc}$ level used for the image in Fig. 1b, no fluorescence was observable.

To determine if cell association of the ZnPc-CEA MAb conjugate $\mathbf{2}$ was based on specific targeting of surface CEA as opposed to non-specific associations, we incubated HT-29 cells with conjugate 2 in the presence and absence of unconjugated anti-CEA antibody. The purpose of this study was to use the unlabeled antibody to compete with the ZnPc-CEA conjugate for antigen binding. In this assay, we imaged and measured fluorescence emission at $700 \mathrm{~nm}$, as shown in Fig. 2. Cells without any added ZnPc-CEA 2 showed minimal fluorescence (Fig. 2a), while cells with ZnPc-CEA 2 showed a high level of fluorescence (Fig. 2b), which was reduced by $\sim 90 \%$ upon addition of a 4 -fold excess of unlabeled antiCEA (Fig. 2c). In addition, cells incubated with unconjugated ZnPc 1 showed only background levels of fluorescence at this wavelength (Fig. 2d).

In order to quantify the fluorescence intensity observed in HT-29 cells at excitation $550 \mathrm{~nm}$ and emission $700 \mathrm{~nm}$, a Kodak in vivo FX imager was used and the results obtained are summarized in Table 1. While unconjugated $\mathrm{ZnPc} 1$ gave a fluorescence signal similar to background, the ZnPc-CEA MAb 2 showed a 37-fold enhancement in fluorescence signal, which was significantly reduced when a 4-fold excess of anti-CEA MAb was added. These results show the very high specificity of the ZnPc-CEA MAb for HT-29 cells, which is 6fold higher than those determined recently with EGFR-targeted ZnPc-peptide ligands [12]. Our results are in agreement with previous reports that show retention of immunoreactivity upon covalent conjugation of aluminum(III)-Pc $\left(\mathrm{AlPcS}_{4}\right)$ to antiCEA 35A7 MAb using a five atom link, and with a Pc/MAb ratio of up to 16 [20].

A promising lead conjugate for in vivo imaging must also be minimally associative with non-colon cancer cells such as mucosal epithelium. To investigate this, we designed a coculture system consisting of HT-29 cells and murine colon epithelial cells obtained from a primary culture of mucosal scrapings [27]. Cells in the co-culture were incubated with $\mathrm{ZnPc}-\mathrm{CEA} \mathrm{MAb} 2$ then stained for CEA and for mucin-like glycoproteins. These glycoproteins are more highly expressed in normal colon epithelia cells than in HT-29 cancer cells. Figure 3 demonstrates that ZnPc-CEA MAb 2 selectively labels HT-29 cells (identified by CEA expression) but not foci of normal colon epithelial cells (which are 
human CEA negative but strongly mucin-positive). This assay therefore indicates a negligible level of non-specific conjugate association with non-target expressing cells.

In addition to associating specifically with the CEA target, the conjugate must also possess minimal cytotoxicity for applicability as imaging agent. We incubated the ZnPc-CEA conjugate $\mathbf{2}$ or unconjugated $\mathrm{ZnPc} \mathbf{1}$ at $10 \mu \mathrm{M}$ (a level 10-fold higher than that necessary to labels cells) with HT-29 cells over a $24 \mathrm{~h}$ period and measured cell number as an index of viability in comparison to untreated cultures. The results obtained are represented in Fig. 4. This experiment demonstrated that conjugate $\mathbf{2}$ had minimal effects on cell number even at $24 \mathrm{~h}$, while unconjugated $\mathrm{ZnPc}$ showed $\sim 40 \%$ decrease, probably due to greater intracellular uptake of unconjugated $\mathrm{ZnPc} 1$ compared with bioconjugate 2, which contains a noninternalizing antibody. This result is in agreement with previous reports demonstrating that non-internalizing antibody conjugates show lower photo-induced toxicity than internalizing conjugates $[18,28]$.

\section{EXPERIMENTAL}

\section{General}

All reagents and solvents were purchased from commercial sources and used directly without further purification. The MAb to human CEA, was purchased from Biodesign International (catalog \# H45655M, $4.24 \mathrm{mg} / \mathrm{mL}$, OD $280 \mathrm{~nm})$. Silica gel $60(230 \times 400$ mesh, Sorbent Technologies) and alumina gel (50-200 $\mu \mathrm{m}$, neutral, standard activity I, Sorbent Technologies) were used for column chromatography. Analytical thin-layer chromatography (TLC) was carried out using polyester backed TLC plates 254 (precoated, $200 \mu \mathrm{m}$ ) from Sorbent Technologies. MicroSpin ${ }^{\mathrm{TM}}$ G-25 Columns were purchased from Amersham Biosciences. Centrifugation was performed on an Eppendorf Centrifuge $5417 \mathrm{R}$ at $24{ }^{\circ} \mathrm{C}$. The UV-vis absorption spectra were measured on an Ultrospec $400 \mathrm{UV}$-vis spectrophotometer from Pharmacia Biotech. ZnPc 1 was prepared as recently reported [19, 12].

\section{Synthesis}

ZnPc-antiCEA 2-The MAb (1 mg) was reconstituted at $2 \mathrm{mg} / \mathrm{mL}$ in $0.1 \mathrm{M} \mathrm{NaHCO}_{3}$ solution. ZnPc $1(1 \mathrm{mg}, 0.001 \mathrm{mmol})$ was dissolved in DMSO $(100 \mu \mathrm{L})$. DIEA $(0.078 \mathrm{mg}$, $0.006 \mathrm{mmol}), \mathrm{HOBt}(0.34 \mathrm{mg}, 0.002 \mathrm{mmol})$ and TBTU $(0.59 \mathrm{mg}, 0.002 \mathrm{mmol})$ were added to the DMSO solution and the reaction solution was stirred for $2 \mathrm{~min}$. The reconstituted MAb solution $(500 \mu \mathrm{L})$ was added into the activated phthalocyanine solution and the combined solution was kept with shaking frequently at room temperature for $1 \mathrm{~h}$. Then the solution was kept at $4{ }^{\circ} \mathrm{C}$ overnight. The crude antibody-Pc conjugate solution was purified by spin column chromatography ( $50 \mu \mathrm{L}$ for each spin column to load, $750 \mathrm{rcf}, 1 \mathrm{~min}, 24^{\circ} \mathrm{C}$ ). The resulting solution was combined together to afford the blue conjugate solution $(900 \mu \mathrm{L})$.

Zn-antiCEA 3-The MAb was reconstituted at $2 \mathrm{mg} / \mathrm{mL}$ in $0.1 \mathrm{M} \mathrm{NaHCO}_{3}$ solution. The ZnPc-PEG (1 mg, $0.001 \mathrm{mmol}$ ) was dissolved in DMSO (50 $\mu \mathrm{L})$. DIEA (0.078 mg, 0.006 $\mathrm{mmol}), \mathrm{HOBt}(0.34 \mathrm{mg}, 0.002 \mathrm{mmol})$ and TBTU $(0.59 \mathrm{mg}, 0.002 \mathrm{mmol})$ were added to the DMSO solution and the reaction solution was stirred for $2 \mathrm{~min}$. The reconstituted MAb 
solution $(500 \mu \mathrm{L})$ was added into the activated Pc solution and the combined solution was kept at room temperature for $2 \mathrm{~h}$, with frequent shaking. Then the solution was kept at $4{ }^{\circ} \mathrm{C}$ for $24 \mathrm{~h}$, with occasional shaking. The crude antibody-Pc conjugate solution was purified by spin column chromatography ( $50 \mu \mathrm{L}$ for each spin column to load, $750 \mathrm{rcf}, 1 \mathrm{~min}, 2{ }^{\circ} \mathrm{C}$ ). The resulting solution was combined to afford the blue conjugate solution $(600 \mu \mathrm{L})$.

\section{Cell studies}

All tissue culture media and reagents were obtained from Invitrogen. HT-29 cells were cultured and maintained in McCoy's 5a Medium Modified supplemented with 10\% FBS and $1 \%$ antibiotic (Penicillin Streptomycin). HT-29 cells were infected with a lentivirus containing the enhanced green fluorescent protein (eGFP; virus purchased from Biogenova, Ellicott City, MD). Green fluorescent cells were sorted by flow cytometry and expanded to generate a line termed "HT-29 eGFP."

Immuno-fluorescence-Cells were washed with D-PBS to remove medium and blocked using a solution of HBSS with $2 \%$ normal goat sera to reduce nonspecific primary antibody binding. The anti-CEA monoclonal antibody (purchased from Biodesign International, Saco, Maine) was then added for $1 \mathrm{~h}$ at room temperature at a final concentration of $40 \mu \mathrm{g} / \mathrm{mL}$. Following removal of the primary antibody, cells were washed and a fluorescent-tagged secondary antibody (Alexa Fluor 488, Molecular Probes Inc.) was applied. Fluorescence was imaged with a Zeiss Axiovert 200 fluorescence microscope with an Omega Optical filter (set 140-2, $607 \mathrm{~nm}$ excitation, $695 \mathrm{~nm}$ emission) and recorded through an Olympus QCapture 5.1 mega pixel color digital camera.

Cytotoxicity-Cancer cells were exposed to ZnPc-CEA conjugate $2(10.0 \mu \mathrm{M}$ concentration) or $\mathrm{ZnPc} 1$ for $24 \mathrm{~h}$ in quadruplicate wells. The wells were then washed to remove non-viable cells. Viable remaining cells were removed via trypsinization and enumerated using a hemocytometer. Control wells consisting of untreated cells were also counted and these control cell numbers were set at $100 \%$ viability. Data points are expression of the viability of treated cells as a percentage of controls.

Competition of CEA MAb binding-HT-29 cells were plated into a 24-well plate at 20,000 cells $/ \mathrm{cm}^{2}$ and allowed to attach overnight. Some wells were incubated over $4 \mathrm{~h}$ with medium alone, the $\mathrm{ZnPc}-\mathrm{CEA}$ conjugate $\mathbf{2}$, simultaneous addition of conjugate $\mathbf{2}(1 \mu \mathrm{M})$ and a $4 \mu \mathrm{g} / \mathrm{mL}$ unconjugated anti-CEA, or $\mathrm{ZnPc} 1$ alone. After incubation media removal and two washes using phosphate-buffered saline, cells were then imaged using a Kodak In Vivo FX Imager with excitation $600 \mathrm{~nm}$ and emission $700 \mathrm{~nm}$ filters. Fluorescence signal emission was quantitated in mean pixel intensity over background using In Vivo FX Pro software.

Co-culture: HT-29 and Murine colonic Epithelial cells-HT-29 cells were spotplated in a $100 \mu \mathrm{L}$ volume in wells of a 12-well dish. Normal colon epithelial cells gently scrapped from fresh mouse colonic mucosa were pelleted to concentrate cells and spotplated next to HT-29 cells and both spots allowed to adhere overnight. This side-by-side coculture was incubated with ZnPc-CEA conjugate 2, then stained for CEA with anti-CEA 
antibody and stained for mucin-like glycoproteins with TRITC-labeled lectin from $U$. europaeus in order to label normal colonic epithelial cells.

\section{CONCLUSION}

Two ZnPcs bearing activated carboxylic acids were conjugated to anti-CEA antibody under similar conditions, using either a short (5-atom) or long (18-atom) linker. The conjugate with the smaller linker gave slightly higher ZnPc/CEA molar ratio (3) and was selected for preliminary evaluation in human colorectal HT-29 cells. Our results demonstrate that the $\mathrm{ZnPc}$ conjugated to anti-CEA enhances approx. 37-fold the association with CEAexpressing colon cancer cells over the unconjugated $\mathrm{ZnPc}$, and that the fluorescence of the conjugate appears both on the surface and within cells. The cell-association was competable with excess anti-CEA suggesting that the conjugate targeted to the CEA epitope rather than non-specifically to the tumor cells. The ZnPc-antiCEA MAb conjugate had minimal cytotoxicity in vitro even at levels well above those necessary for fluorescence signal detection.

\section{Acknowledgments}

The work described was supported by the US National Institutes of Health, grant number R21 CA139385.

\section{References}

1. American Cancer Society Detailed Guide. Colon and rectum cancer what are the key statistics for colorectal cancer?. http://www.cancer.org/cancer/colonandrectumcancer/detailedguide/colorectalcancer-key-statistics

2. Kiesslich R, Goetz M, Vieth M, Galle PR, Neurath MF. Nat Clin Pract Oncol. 2007; 4:480-490. [PubMed: 17657253]

3. Van den Broek FJ, Fockens P, Dekker F. Aliment Pharmacol Ther. 2007; 26:91-99. [PubMed: 18081653]

4. American Cancer Society Detailed Guide. Can colorectal polyps and cancer be found early?. http:// www.cancer.org/cancer/colonandrectumcancer/detailedguide/colorectal-cancer-detection

5. Baxter NN, Goldwater MA, Paszat LF, Saskin R, Urback DR, Rabeneck L. Ann Internal Medicine. 2009; 150:1-8.

6. Liu TM, Chu SW, Sun CK, Lin BL, Cheng C, Johnson I. Scanning. 2001; 23:249-254. [PubMed: 11534811]

7. Sharman, WM.; Van Lier, JE. The Porphyrin Handbook. Kadish, KM.; Smith, KM.; Guilard, R., editors. Vol. 15. Academic Press; Boston: 2003. p. 1-60.

8. Ben-Hur, E.; Chan, W-S. The Porphyrin Handbook. Kadish, KM.; Smith, KM.; Guilard, R., editors. Vol. 19. Academic Press; Boston: 2003. p. 1-30.

9. Erk, P.; Hengelsberg, H. The Porphyrin Handbook. Kadish, KM.; Smith, KM.; Guilard, R., editors. Vol. 19. Academic Press; Boston: 2003. p. 106-146.

10. Dougherty TJ, Gomer CJ, Henderson BW, Jori G, Kessel D, Korbelik M, Moan J, Peng Q. J Natl Cancer Inst. 1998; 90:889-905. [PubMed: 9637138]

11. Pandey RK. J Porphyrins Phthalocyanines. 2000; 4:368-373.

12. Ongarora BG, Fontenot KR, Hu X, Sehgal I, Satyanarayana-Jois SD, Vicente MGH. J Med Chem. 2012; 55:3725-3738. [PubMed: 22468711]

13. Hudson R, Boyle RW. J Porphyrins Phthalocyanines. 2004; 8:954-975.

14. Chau I, Allen MJ, Cunningham D, Norman AR, Brown G, Ford HE, Tebbutt N, Tait D, Hill M, Ross PJ, Oates J. J Clin Oncol. 2004; 22:1420-1429. [PubMed: 15007086] 
15. Kaushal S, McElroy MK, Luiken GA, Talamini MA, Moossa AR, Hoffman M, Bouvet M. J Gastrointest Surg. 2008; 12:1938-1950. [PubMed: 18665430]

16. Pretlow TP, Roukhadze EV, O'Riordan MA, Chan JC, Amini SB, Stellato T. A. Gastroenterology. 1994; 107:1719-1725. [PubMed: 7958683]

17. Hammarstrom S. Semin Cancer Biol. 1999; 9:67-81. [PubMed: 10202129]

18. Carcenac M, Dorvillius M, Garambois V, Glaussel F, Larroque C, Langlois R, Hynes NE, van Lier JE, Pelegrin A. Br J Cancer. 2001; 85:1787-1793. [PubMed: 11742503]

19. Ongarora BG, Hu X, Li H, Fronczek FR, Vicente MGH. Med Chem Comm. 2012; 3:179-194.

20. Carcenac M, Larroque C, Langlois R, van Lier JE, Artus JC, Pelegrin A. Photochem Photobiol. 1999; 70:930-936. [PubMed: 10628305]

21. Hudson R, Carcenac M, Smith K, Madden L, Clarke OJ, Pelegrin A, Greenman J, Boyle RW. Br J Cancer. 2005; 92:1442-1449. [PubMed: 15812551]

22. Kaushal S, McElroy MK, Luiken GA, Talamini MA, Moossa AR, Hoffman RM, Bouvet M. J Gastrointest Surg. 2008; 12:1938-1950. [PubMed: 18665430]

23. Sutton JM, Clarke OJ, Fernandez N, Boyle RW. Bioconjugate Chem. 2002; 13:249-263.

24. Vrouenraets MB, Visser GWM, Stigter M, Oppelaar H, Snow GB, van Dongen GAMS. Cancer Res. 2001; 61:1970-1975. [PubMed: 11280754]

25. Smith K, Malatesti N, Cauchon N, Hunting D, Lecomte R, van Lier JE, Greenman J, Boyle RW. Immunology. 2011; 132:256-265. [PubMed: 21039468]

26. Vira S, Mekhedov E, Humphrey G, Blank PS. Anal Biochem. 2010; 402:146-150. [PubMed: 20362543]

27. Bartsch I, Zschaler I, Haseloff M, Steinberg P. Cell Dev Biol Animal. 2004; 40:278-284.

28. Del Governatore M, Hamblin MR, Piccinini EE, Ugolini G, Hasan T. Br J Cancer. 2000; 82:56-64. [PubMed: 10638967] 


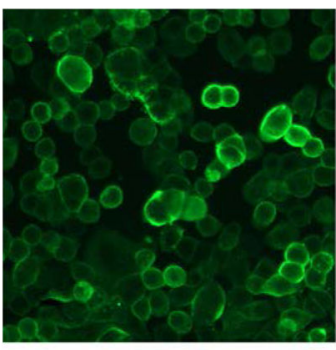

(a)

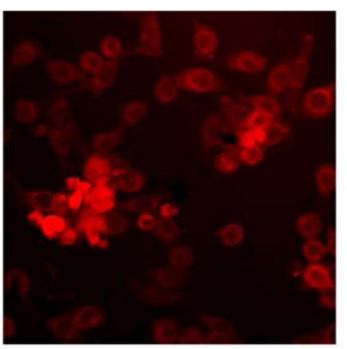

(b)

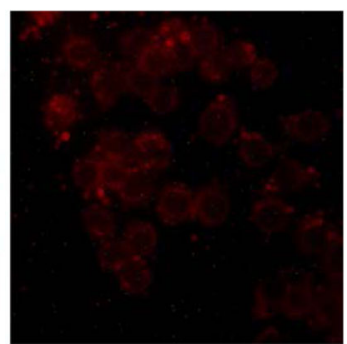

(c)

Fig. 1.

Images of human colorectal HT-29 cells in the presence of: (a) anti-CEA MAb, showing surface expression of CEA. (b) ZnPc-CEA MAb 2 at $1 \mu \mathrm{M}$ concentration, showing fluorescence emission at $700 \mathrm{~nm}$. (c) Unconjugated $\mathrm{ZnPc} 1$ at $10 \mu \mathrm{M}$ concentration, showing low uptake with cytoplasmic staining (at $1 \mu \mathrm{M}$, no fluorescence is observed, image not shown) 


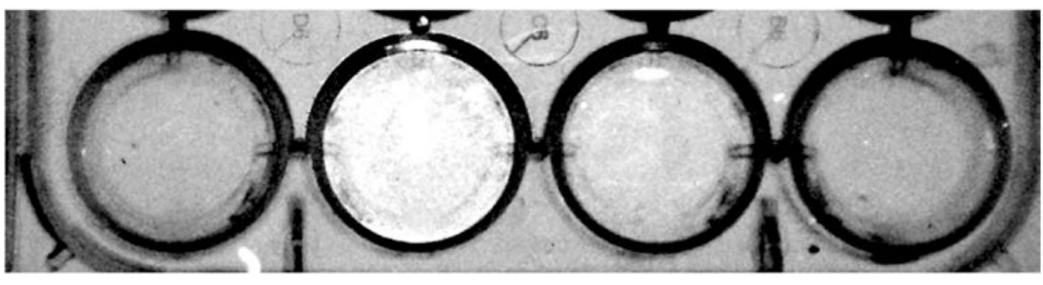

(a)

(b)

(c)

(d)

Fig. 2.

ZnPc-CEA MAb conjugate targets CEA associated with HT-29 cells. (a) HT-29 cells containing no ZnPc (control). (b) Cells incubated with $1 \mu \mathrm{M}$ ZnPc-CEA 2. (c) Cells incubated with $1 \mu \mathrm{M}$ ZnPc-CEA plus a 4-fold excess of unconjugated anti-CEA antibody. (d) Cells incubated with unconjugated ZnPc 1 


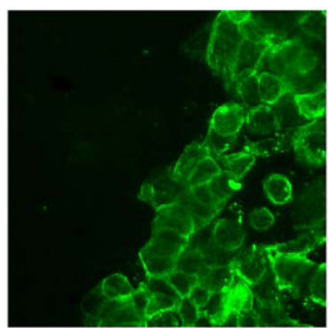

(a)

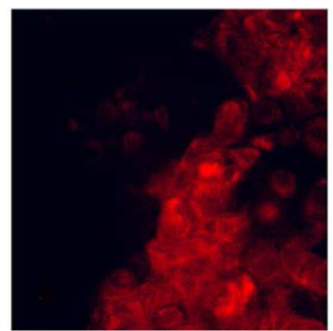

(b)

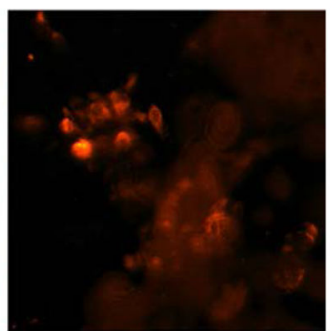

(c)

Fig. 3.

Co-culture of HT-29/normal colon epithelial cells incubated with ZnPc-CEA conjugate 2 at $1 \mu \mathrm{M}$ concentration. (a) Staining with anti-CEA antibody reveals the HT-29 portion of the co-culture. (b) Imaging at $700 \mathrm{~nm}$ emission shows association of conjugate 2 with the CEAexpressing cells. (c) TRITC-labeled lectin from $U$. europaeus identifies mucin glycoproteins, more abundantly expressed on normal colonic epithelial cells 


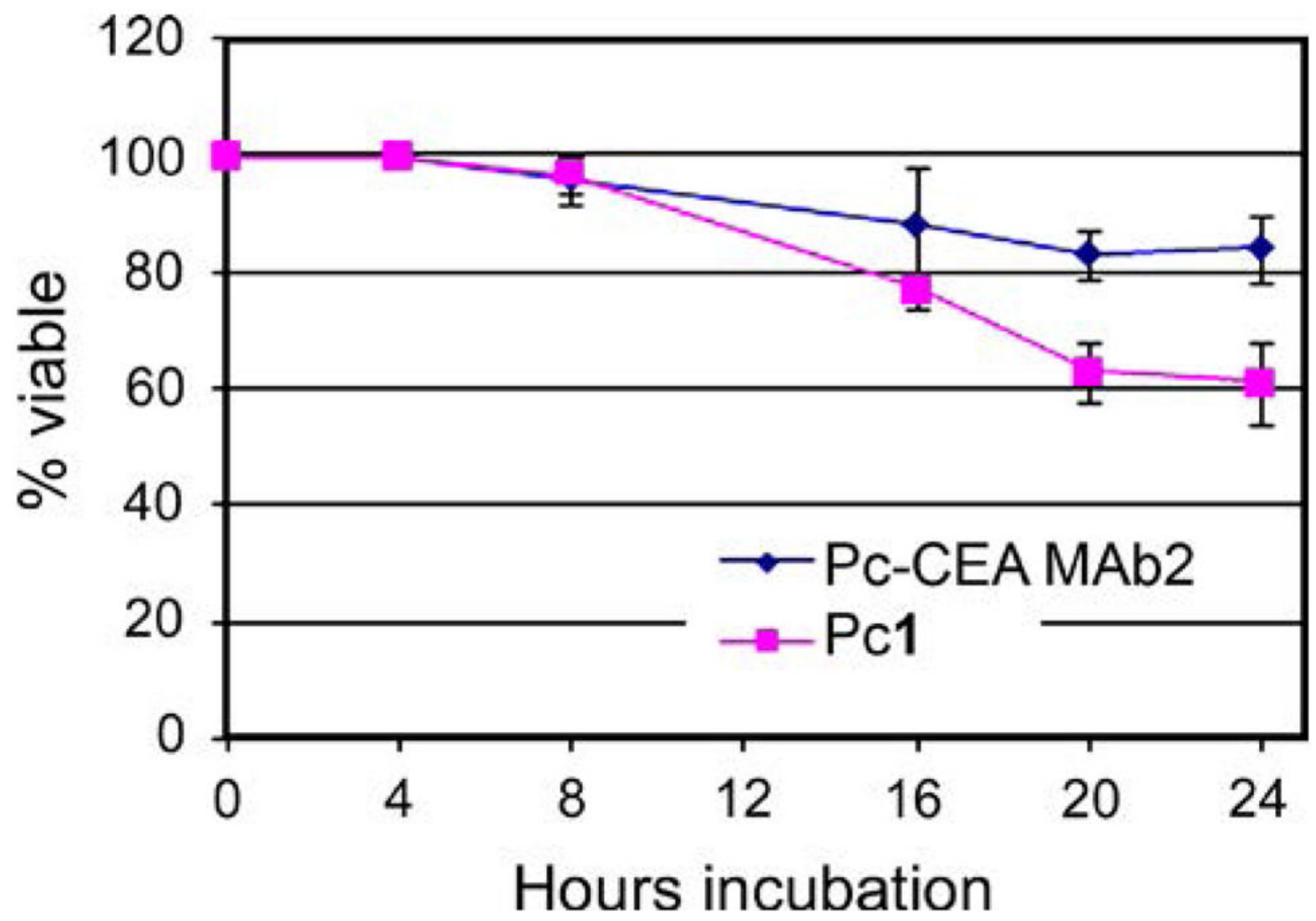

Fig. 4.

Cytotoxicity in HT-29 cells of ZnPc-CEA conjugate $\mathbf{2}$ and ZnPc $\mathbf{1}$ at $10 \mu \mathrm{M}$ concentrations.

Data represents mean \pm s.d. of four replicates 


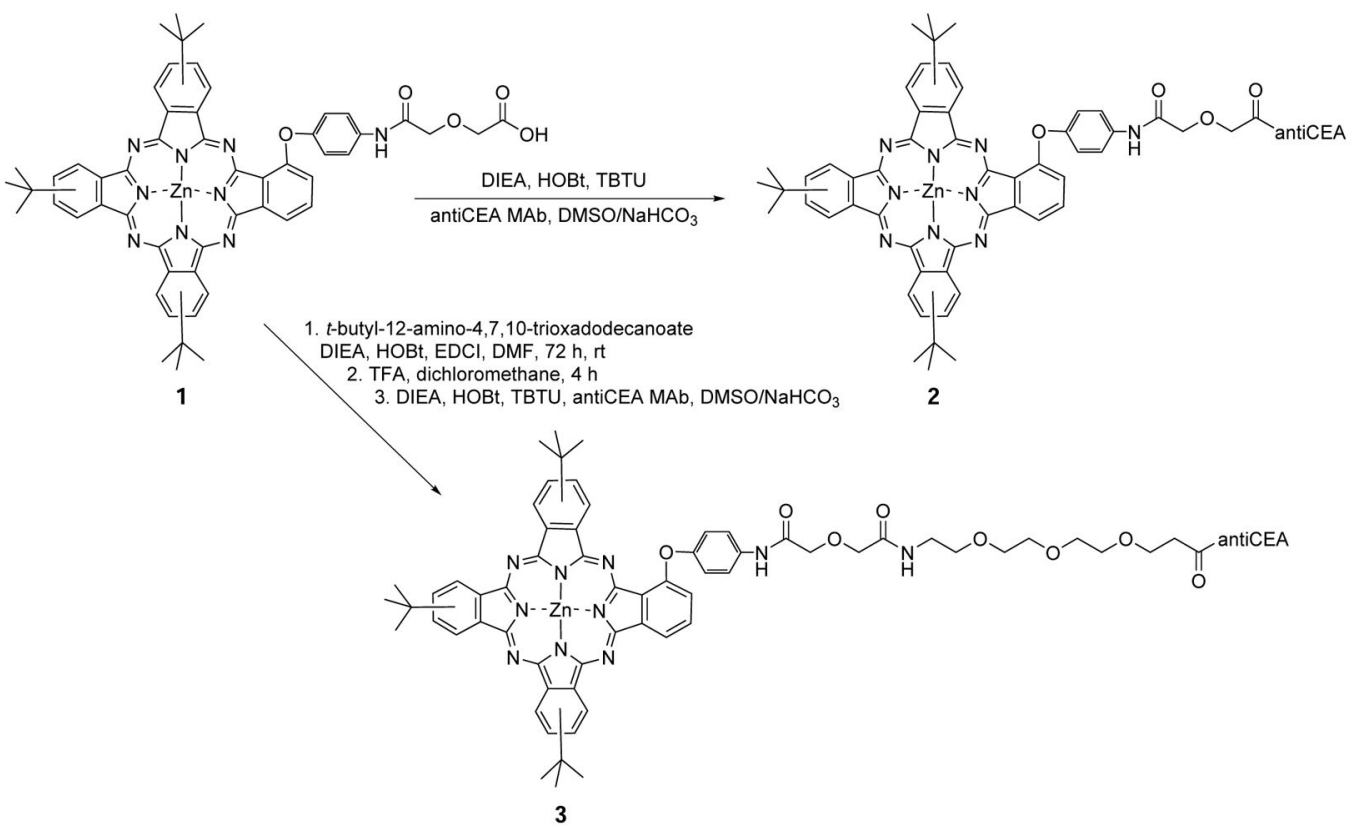

Scheme 1.

Synthesis of ZnPc-antiCEA MAb bioconjugates $\mathbf{2}$ and $\mathbf{3}$ 


\section{Table 1}

Quantification of mean fluorescence intensity in HT-29 cells (excitation 550, emission 700). Fluorescent emissions of HT-29 cells were quantitated in a Kodak In Vivo FX imager based on units of fluorescence in net pixels per well above background for three experiments. Data reflects mean \pm s.d.

\begin{tabular}{lccc}
\hline No additive to media & ZnPc-antiCEA 2 & ZnPc-antiCEA 2 + excess unconjugated anti-CEA & ZnPc 1 alone \\
\hline $18 \pm 5$ & $407 \pm 22$ & $41 \pm 9$ & $11 \pm 7$ \\
\hline
\end{tabular}

